\title{
Migratory and reproductive behaviour of female adult Atlantic salmon, Salmo salar L., in a spawning stream
}

\author{
J. L. Baglinière, G. Maisse AND A. Nihouarn* \\ Station de Physiologie et d'Ecologie des Poissons, INRA, 65 Rue de St Brieuc, 35042 \\ Rennes Cedex, France, ${ }^{*}$ Délégation Régionale de l'Ouest du Conseil Supérieur de la Pêche, \\ 84 Rue de Rennes, 35510 Cesson Sevigne, France
}

(Received 24 April 1989, Accepted 8 November 1989)

\begin{abstract}
Migration and spawning behaviour of eight Atlantic salmon adult females were analysed by radio-tracking in relation to the degree of sexual maturity in a spawning tributary of the $\mathbf{R}$. Sélune. Six of them were grilse and four of them were ripe. All the fish migrated upstream until reaching their spawning site at a distance of 4-12 km from the trap. The daily migration rate up to this site was inversely correlated with the length of the female. Spawning occurred in all fish at the same time when the water temperature increased dramatically. Spawning lasted 1-10 days according to the fish. After spawning, females quickly moved downstream only small distances and then stayed in approximately the same location until death. This study concluded that ripeness did not influence behaviour on the spawning migration and describes certain characteristics of the reproductive phase in a spawning tributary.
\end{abstract}

Key words: Atlantic salmon; migration; reproduction; behaviour; radio-tracking.

\section{INTRODUCTION}

When adult salmon reach the river, migration takes place generally in three successive phases: rapid movement upstream for either long or short distances, then a long residence period, followed by a short upstream migration just before spawning (Hawkins \& Smith, 1986; Heggberget et al., 1988). Numerous studies have been carried out, notably on the first phase, to determine distances and speed of migration. Values thus obtained seem to depend upon the time of year of the study, size of the fish, and the time they have spent in the sea (Table I). The reproductive behaviour of Atlantic salmon has been well documented (Jones \& King, 1949; Thioulouse, 1971; Fontenelle, 1975; Beall \& Marty, 1983). However, the third migratory phase, corresponding to upstream movement of the fish towards the spawning zones, has hardly been studied, with the exception of work carried out by Hawkins \& Smith (1986). Our work was based on this third phase in a tributary of the River Selune, the R. Oir, in lower Normandy. First observations showed that adult salmon entered this tributary late in the autumn just before spawning. Furthermore, it was found that both ovulated and non-ovulated females were caught at the trap. In this study, radio-tracking was used to investigate the migratory and reproductive behaviour of these females in relation to their stage of maturity before and after spawning.

\section{MATERIALS AND METHODS}

The experiment was carried out on the R. Oir, a right bank tributary of the downstream part of the R. Sélune, a river in the Armoricain Massif, between 5 December 1988 and 


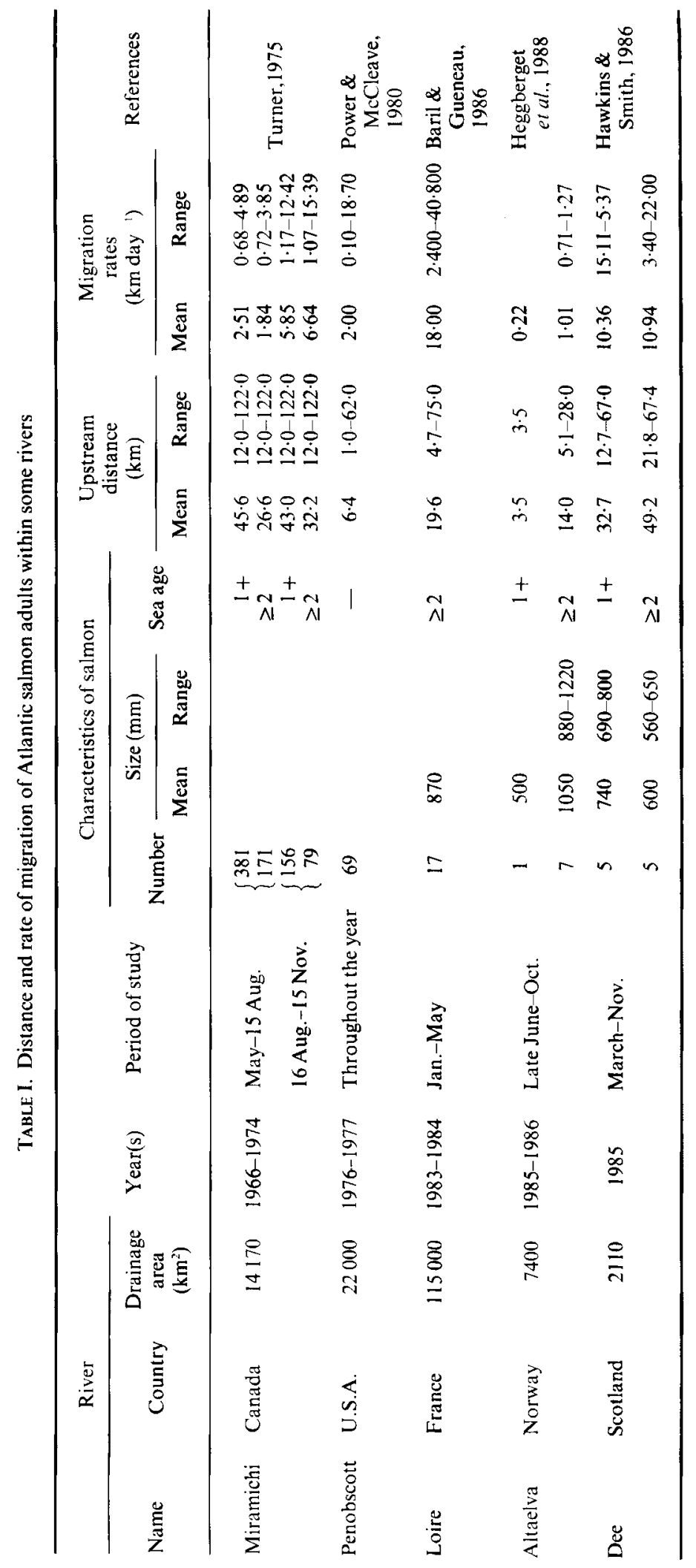




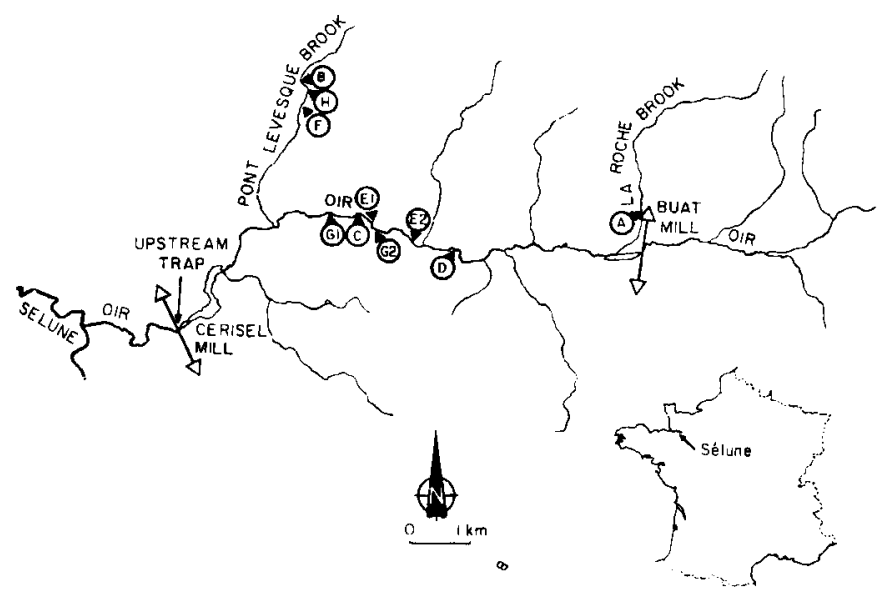

Fig. 1. The water course of the R. Oir. $\triangleleft-\downarrow$, limits of the studied zone during the spawning season. There are very few spawning grounds below the trap which is located at $2.3 \mathrm{~km}$ from the confluence with the R. Selune. The spawning sites are marked with the letters corresponding to the eight tracked fish (see text). C and D were 2 sea-winter salmon.

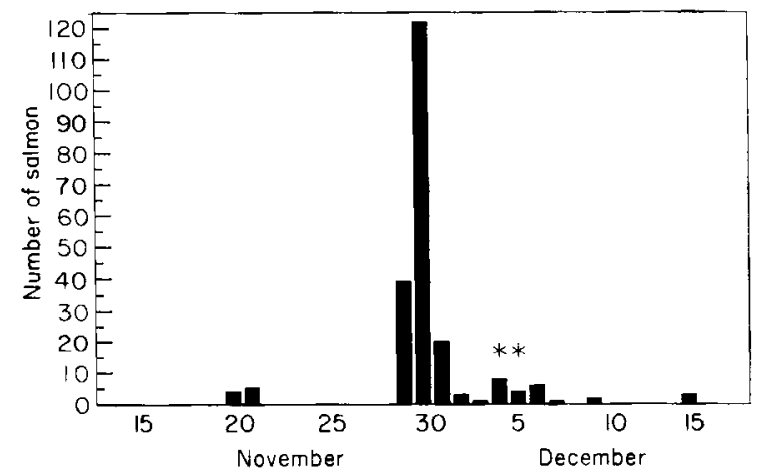

FIG. 2. Migration of Atlantic salmon adults in the R. Oir via the trap at Cerisel Mill in 1988. Most migration took place in late autumn, a short time before spawning; only $4 \%$ of the total run was caught before 15 November. Asterisks mark date of capture of salmon adult females used in this study.

9 January 1989. The characteristics of the environment have been described by Baglinière et al. (1988). The tributary is $19.5 \mathrm{~km}$ long with a drainage area $85 \mathrm{~km}^{2}$ (Fig. 1). The spawning zone for salmon is distributed over $10.1 \mathrm{~km}$ of the main course of the river between a point $2.2 \mathrm{~km}$ upstream of the trapping site and Buat watermill dam, which is impassable. The trap is located $2.3 \mathrm{~km}$ from the confluence with the $\mathrm{R}$. Sélune. Downstream from the trap, the $R$. Oir is deep and has few sites suitable for spawning. In the spawning zone, the average width of the river is $3.5 \mathrm{~m}$ and there are seven tributaries, including Pont Levesque brook $(5.4 \mathrm{~km})$ and $\mathrm{La}$ Roche brook $(3.4 \mathrm{~km})$.

Eight female adult salmon $(12.7 \%$ of the total number of females released upstream from the trap) where trapped at Cerisel watermill on 4 and 5 December 1988, towards the end of the period of reproduction migration (Fig. 2). These fish were grilse and 2 sea-winter salmon and had fork lengths ranging from 628 to $722 \mathrm{~mm}$. Four of these females had ovulated (Table II). 
TABLE II. Characteristics of female Atlantic salmon adults studied by radio-tracking in the R. Oir

\begin{tabular}{|c|c|c|c|c|c|}
\hline \multirow{2}{*}{ Identity } & \multirow{2}{*}{$\begin{array}{c}\text { Fork } \\
\text { length } \\
(\mathrm{mm})\end{array}$} & \multirow{2}{*}{$\begin{array}{c}\text { Date } \\
\text { of } \\
\text { capture }\end{array}$} & \multicolumn{2}{|c|}{ Age } & \multirow{2}{*}{$\begin{array}{c}\text { State } \\
\text { of } \\
\text { maturity }\end{array}$} \\
\hline & & & River & Sea & \\
\hline $\mathrm{A}$ & 644 & $4-12$ & 2 & $1+$ & Ovulated \\
\hline $\mathrm{B}$ & 690 & $4-12$ & 2 & $1+$ & Ovulated \\
\hline $\mathrm{C}$ & 753 & $5-12$ & 1 & $\geq 2^{*}$ & Ovulated \\
\hline $\mathrm{D}$ & 649 & $5-12$ & 2 & $1+$ & Ovulated \\
\hline $\mathrm{E}$ & 650 & $4-12$ & 2 & $1+$ & Non-ovulated \\
\hline $\mathrm{F}$ & 697 & $4-12$ & 1 & $1+$ & Non-ovulated \\
\hline $\mathrm{G}$ & 772 & $4-12$ & $i$ & $\geq 2^{*}$ & Non-ovulated \\
\hline $\mathrm{H}$ & 628 & $5-12$ & 2 & $1+$ & Non-ovulated \\
\hline
\end{tabular}

*Scale edge eroded.

After anaesthesia ( $3 \mathrm{ml}$ phenoxyethanol per 101 water), a lubricated radio transmitter (ATS brand) was placed in the fish's stomach with the help of two plastic tubes introduced in to the oesophagus, and a $29-\mathrm{cm}$ antenna was brought out through the lower part of the gill (McCleave et al., 1978). This all took less than $1 \mathrm{~min}$. The salmon was then placed in a tank, immersed in the head bay of the trap, from which it could leave freely. All fish were handled and tagged on the 5 December. The radio-transmitter weighed $16 \mathrm{~g}$ and was $45 \mathrm{~mm}$ long and $16 \mathrm{~mm}$ wide. Its working life was between 140 and 180 days and its signal rate was $1 \mathrm{~s}^{-1}$. Each tag operated on a different radio frequency between 48 and $49 \mathrm{MHz}$. The transmitter range was between 0.5 and $1 \mathrm{~km}$ depending on the terrain. When size and volume of the transmitter were compared to that of the fish, it was considered that stress following insertion was negligible (Solomon \& Storeton-West, 1983; Baril \& Gueneau, 1986; Heggberget et al., 1988).

Tagged salmon were followed using a single channel receiver. Positioning of fish was carried out using a directional mobile antenna (portable or car transportable).

Fish were located daily, using two readings for cross-checking purposes, enabling positioning to within $10 \mathrm{~m}$ on a $1: 2000$ scale map. When conditions necessitated, positioning was done on the river bank. (Redd observations were made in good conditions due to slow river flow during the experimental period.)

Females were identified by the letters $\mathrm{A}$ to $\mathrm{H}$ and their position was measured in kilometres from the trap. The spawning sites for the eight fish were plotted on the map, using these letters with an index-number when the femal spawned several times.

All the females were recorded dead and were opened to estimate ova retention rates.

Water level and temperature were recorded during this period; barometric pressure and cloud cover were noted twice a day (Fig. 3).

\section{RESULTS}

\section{PRE-SPAWNING BEHAVIOUR}

Three females (A, B and F), of which two $(A, B)$ were ovulated left the head bay on the day of release ( 5 December) at the same time as an increase in the water level. The two other ovulated females (C and $D)$ began their migration a day later, at the peak of the rise of water level. The last three fish began their migration on the second $(\mathrm{G}$ and $\mathrm{H})$ and the third $(\mathrm{E})$ day after release, when the water level had decreased.

Speed of migration was generally rapid for the first two days following departure, with seven females covering a distance during this period of between 54 and 

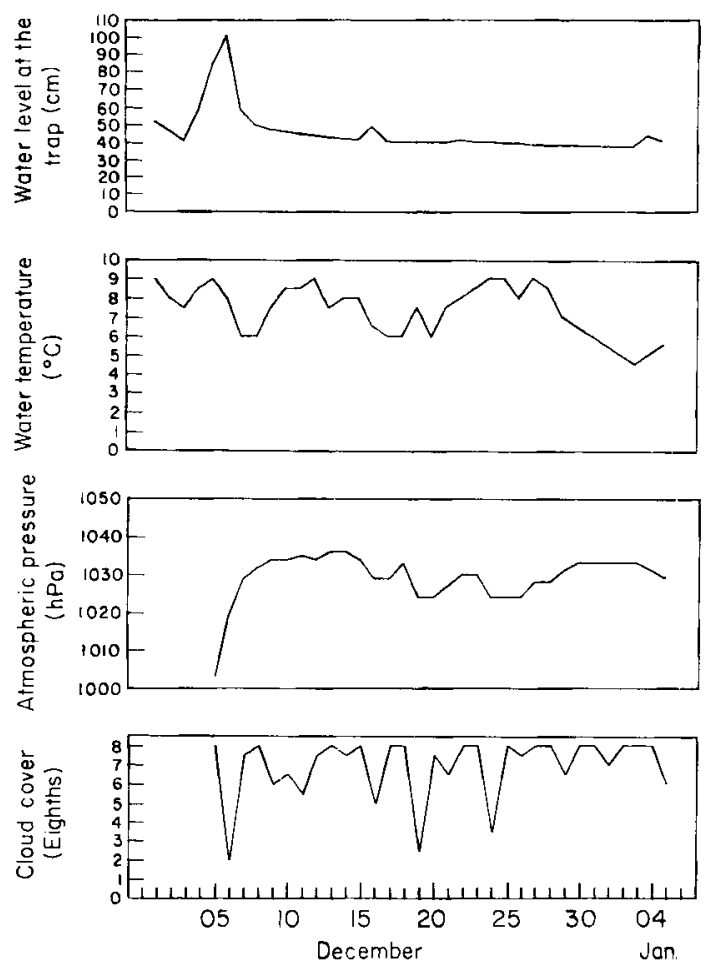

FIG. 3. Evolution of climatic factors during the period of study (5 December 1988-4 January 1989) on the R. Oir.

$100 \%$ of the total distance they ran upstream. Fish G, however, only covered $22 \%$ of the distance (Fig. 4). During this phase the water temperature decreased from 9 to $6^{\circ} \mathrm{C}$. Speed of migration was related to the size of the fish and not to its maturation stage. On the first day, the migration rate was inversely correlated to fork length of the fish. However, this relationship was reversed on the third day (Table III). The negative correlation between the size of the fish and the daily migration rate up to the spawning site was lower but still significant (Table III). Upstream migration ended 5-7 days after release at the same time as the water level became stable (Fig. 4). Atmospheric pressure and cloud cover did not seem to have any effect during this period.

The positioning of the furthest point of migration did not appear to depend on the stage of maturity of the fish at the trap but may have been influenced by its sea age. Four grilse females ran upstream in the tributaries. Three of them (B, F and $\mathrm{H}$ ), of which one $(\mathrm{H})$ had ovulated, migrated rapidly in Pont Levesque brook and after 3-6 days reached between 5.65 and $5.9 \mathrm{~km}$ from the trap (approximately $2 \mathrm{~km}$ from the confluence with the river) (Figs 1,4). Ovulated female A ascended La Roche brook, in the upper part of the spawning area, to reach, after 7 days of migration, a distance of more than $12 \mathrm{~km}$ from the trap and $0.5 \mathrm{~km}$ from the confluence (Fig. 4). The other four females, of which two were ripe at the trap, stayed in the lower part of the river after having covered distances of between 4 and 
TABLE III. Relationships between the fork length of the adult female salmon and their daily migration rate in the $\mathrm{R}$. Oir

\begin{tabular}{|c|c|c|c|c|c|c|c|}
\hline \multicolumn{2}{|c|}{ Fish } & \multirow[b]{2}{*}{$\begin{array}{c}\text { Date } \\
\text { of } \\
\text { departure }\end{array}$} & \multicolumn{3}{|c|}{$\begin{array}{l}\text { Daily migration rate }(\mathrm{km} \\
\left.\mathrm{day}^{-1}\right)\end{array}$} & \multicolumn{2}{|r|}{ Spawning } \\
\hline Identity & $\begin{array}{c}\text { Fork } \\
\text { length } \\
(\mathrm{mm})\end{array}$ & & $\begin{array}{l}\text { First } \\
\text { day }\end{array}$ & $\begin{array}{l}\text { Third } \\
\text { day }\end{array}$ & $\begin{array}{l}\text { Up to } \\
\text { spawning } \\
\text { site }\end{array}$ & $\begin{array}{l}\text { Distance } \\
\text { from } \\
\operatorname{trap}(\mathrm{km})\end{array}$ & Site \\
\hline $\mathrm{H}$ & 628 & $07 / 12$ & $5 \cdot 10$ & $0 \cdot 10$ & 1.88 & $5 \cdot 65$ & Pont Levesque brook \\
\hline$\ddot{A}$ & 644 & $05 / 12$ & $4 \cdot 10$ & $1 \cdot 70$ & 1.55 & $12 \cdot 40$ & La Roche brook \\
\hline D & 649 & $06 / 12$ & 3.96 & 0.08 & 0.99 & 5.94 & R. Oir \\
\hline E & 650 & $08 / 12$ & $4 \cdot 42$ & 0.00 & $2 \cdot 31$ & $4 \cdot 62^{*}$ & R. Oir \\
\hline B & 690 & $05 / 12$ & $1 \cdot 23$ & 0.60 & 0.98 & 5.90 & Pont Levesque brook \\
\hline $\mathrm{F}$ & 697 & $05 / 12$ & $2 \cdot 26$ & 0.60 & $1 \cdot 14$ & $5 \cdot 70$ & Pont Levesque brook \\
\hline $\mathrm{C}$ & 753 & $06 / 12$ & 0.90 & $1 \cdot 70$ & 0.74 & 4.49 & R. Oir \\
\hline $\mathrm{G}$ & 772 & $07 / 12$ & 0.86 & $2 \cdot 80$ & 0.71 & $4 \cdot 26^{*}$ & R. Oir \\
\hline \multicolumn{3}{|c|}{ Value of correlation } & 0.92 & 0.76 & -0.75 & & \\
\hline \multicolumn{3}{|c|}{ Level of significance $(P)$} & $<0.01$ & $<0.05$ & $<0.05$ & & \\
\hline
\end{tabular}

*First spawning.

$6 \mathrm{~km}$ after 2-4 days of migration; amongst these fish, 2 sea-winter females covered the shortest distances (Fig. 4).

Finally, at the furthest point of migration, just before spawning, small movements were seen both upstream and downstream in certain grilse females (Fig. 4).

\section{SPAWNING}

Spawning took place at approximately the furthest point of migration and began at suitable sites between 10 and 12 December for all females (Fig. 4). It occurred principally at night and followed an increase in water temperature from 6 to $9^{\circ} \mathrm{C}$. Females A, B, C, D, F and $\mathrm{H}$ layed their eggs at one site; the other two, E and G, spawned at two sites, the second spawning occurring on 19 and 20 December, very soon after an upstream migration over a distance of $0 \cdot 58-1 \mathrm{~km}$. The duration of this phase was shorter (1-2 days) for the females spawning in brooks than for those spawning in the river (5-9 days). Water temperature decreased from 9 to $6^{\circ} \mathrm{C}$ from the start of spawning to the end of the reproduction period.

\section{POST-SPAWNING BEHAVIOUR}

Female $F$ was found to be dead at the spawning site (Pont Levesque brook) on 12 December, one day after it was seen digging a redd (Fig. 4). Females A, B, D, E and $\mathrm{H}$ moved downstream immediately after spawning, whereas the other two, $\mathrm{C}$ and $\mathrm{G}$ ( 2 sea-winter salmon), remained near the spawning site before the downstream migration (Fig. 4). Generally, the fish moved only small distances $(0.34 \mathrm{~km}-1.3 \mathrm{~km})$ except for female A $(2.1 \mathrm{~km})$, some fish moving both upstream and downstream (Fig. 4). The females then stayed in about the same position between 24 and 31 December at distances of 0.72 and $1.90 \mathrm{~km}$ from the spawning site. During this period, female A descended into the river after having spawned in La Roche brook, whereas the two females present in Pont Levesque brook stayed in the tributary. 

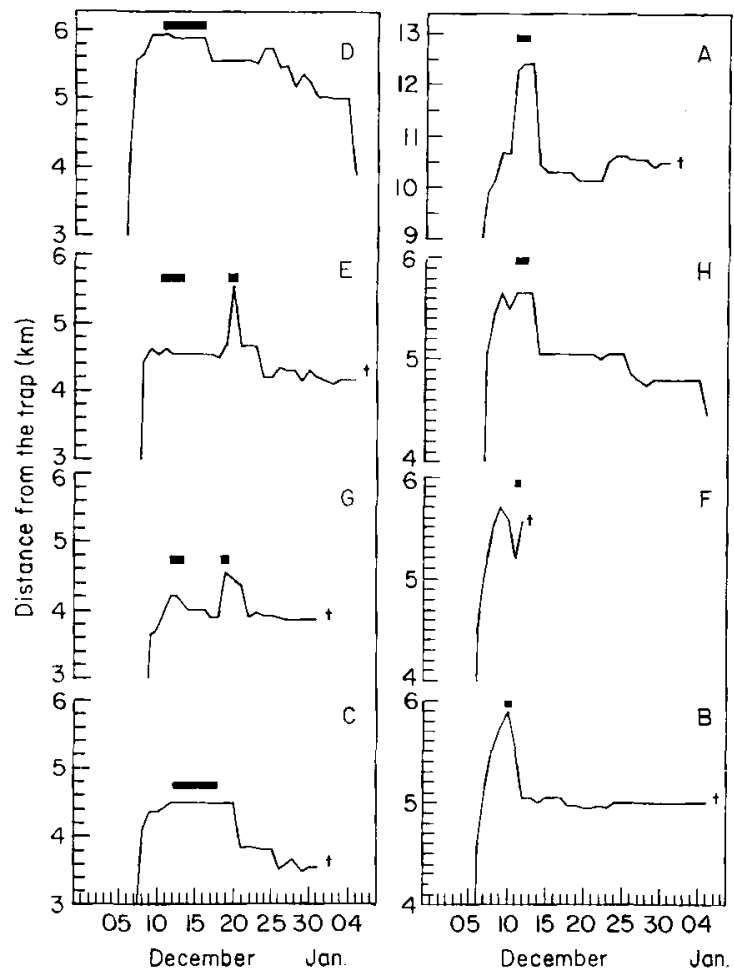

FIG. 4. Upstream and downstream migration of eight female salmon (A-H) studied before, during and after spawning (extended distance scale) ( $\mathbf{Q}$, spawning; $\dagger$, death). Females A, B, C and D were ovulated;C and $G$ were 2 sea-winter salmon. The left side of the figure depicts migration of females spawning in the $R$. Oir, the right side migration of females spawning in the tributaries (A in La Roche brook, H,F and $B$ in Pont Levesque brook; see Fig. 1).

All the females were found dead between 5 and 8 January 1989. The advanced state of decomposition of females A, C, E and G indicated that death occurred between 31 December and 3 January (Fig. 4) whereas the relatively good appearance of the others $(\mathrm{B}, \mathrm{D}$ and $\mathrm{H})$ indicated that death occurred between the 5 and 9 January. Between 2 and 39 ova were found inside the abdominal cavity of these fish. The relationship between fork length and fertility of the 1988 ascending females (unpublished data) enables estimation of the average rate of egg retention as $0.5 \%$ of the average reproductive potential of these fish. However, female F, found dead on the 12 December, had only partially spawned, as 3390 out of an estimated potential of 5878 ova remained in the abdominal cavity.

\section{DISCUSSION}

Certain characteristics of migratory reproduction and reproductive behaviour of female adult salmon in the R. Oir have been elucidated as a result of this work.

\section{INFLUENCE OF THE STAGE OF SEXUAL MATURITY}

The stage of sexual maturity at the trap (ovulated or non-ovulated) does not seem to have any effect on the speed of migration nor on the date or location 
of spawning. However, it is possible that handling stress could have induced ovulation in non-ripe females. This has often been observed in rainbow trout, Onchorhynchus mykiss (Walbaum), after transport at the beginning of the spawning period (G. Maisse, pers. commun.). Nevertheless, the fact that a female had ovulated does not signify that she had migrated rapidly over short distances to reproduce earlier at unsuitable sites (downstream part of the Oir basin). On the contrary, the longest distance covered was by an ovulated female (A) which spawned at the upstream limit of the accessible area; this was at more than $12 \mathrm{~km}$ from the trap, which is the equivalent of two or three times the distance covered by the other fish from the trap. Furthermore, ovulated females waited 6 or 7 days before spawning. All fish spawned at comparable sites (tail of a pool, large substrate size) known to be favourable and described by Fontenelle (1975), Baglinière et al. (1979), Heggberget et al. (1986) and Marty et al. (1986). The only difference between the behaviour of ovulated and non-ovulated females was the time between release and the beginning of the upstream run. This difference may be due to a stronger stimulation of migratory behaviour in ripe females during periods of rising waters. However, it is possible that it related to the effects of handling of the fish: Solomon \& Storeton-West (1983) think these effects may be negligible, although in a similar study carried out on two Norwegian rivers, Heggberget et al. (1988) considered that these negative effects were most pronounced during the first 5 days after release and that they could modify migratory behaviour during this period. Nevertheless, no reject of radio transmitters or downstream running (considered to be a response to stress by Baril \& Gueneau (1986)) was observed.

\section{MIGRATORY BEHAVIOUR}

Migratory behaviour of females before reaching the trap is unknown. In particular, it is not known whether these fish stay for a long time in the downstream part of the R. Oir or whether they ascend this river when water flow becomes attractive. However, our observations show that reproductive migration occurs with an increase in water flow, as all females were captured in periods of floods. This confirms the important influence of this parameter on salmon movements in rivers (Swain \& Champion, 1968; Alabaster, 1970; Buck \& Youngson, 1982; Dunkley \& Shearer, 1982; Jensen et al., 1986). The influence of water flow can vary according to the period of the year and the number of obstructions in the river's course (Hawkins \& Smith, 1986).

The migratory behaviour of the eight tracked females was more or less similar before and after spawning, and was characterized by three phases: (1) an initial rapid upstream movement followed by a smaller movement, mainly upstream, a few days prior to spawning (this confirms the observations of Hawkins \& Smith (1986)), which seem to occur more particularly during the decreasing water level phase; (2) spawning activity lasting 1-9 days according to the fish and the location of spawning site; (3) a downstream rapid movement, usually over a small distance $(0 \cdot 5-2 \mathrm{~km})$, general immediately after spawning, the female salmon thus not showing watch-keeping behaviour on the spawning grounds (these observations agree with those of Jones (1959) and Thioulouse (1971)), after which the fish stay at the same place until their death.

In this study, it was impossible to know at what time of day the fish preferred to move. 


\section{INFLUENCE OF WATER TEMPERATURE ON SPAWNING}

In the R. Oir, spawning of the eight females took place almost simultaneously and seemed to be triggered by an increase in water temperature. This observation is in concordance with that of Heggberget (1988) who demonstrated the importance of the thermal factor in regulating the beginning and the peak of spawning of Atlantic salmon in 16 Norwegian rivers. The first study of reproduction in Atlantic salmon in the Scorff, another river in the Armoricain Massif, suggested that changes in temperature above $5^{\circ} \mathrm{C}$ did not influence spawning (Baglinière et al., 1979). However, that study was carried out by counting the number of redds, and not by using radio-tracking, and during the 3 years of the study the water flow was always rapid, which could have masked any influence of temperature on the triggering of spawning, whereas in the R. Oir, water flow remained slow throughout the reproductive period, which certainly helped to identify the temperature effect.

\section{MORTALITY AND EGG RETENTION RATE AFTER SPAWNING}

All the females were collected dead after the spawning. This fact agrees with the very low number of female kelts recaptured in the downstream trap $(9 / 54$ in 1988; unpubl. data).

The calculated rate of egg retention (average $5 \%$ ) was low. In sockeye salmon, Oncorhynchus nerka, such a retention rate seems to be minimal (Manzer \& Miki, 1986) and is independent of variations in water flow during spawning period (Chapman et al., 1986). With spawning Atlantic salmon, in an experimental channel, the average retention rate was $7 \cdot 4 \%$ of the theoretical reproductive potential, but it increased with an increase in female density (Beall \& Marty, 1987). Further study is necessary to verify this retention rate over several years. If this very low value is confirmed, the relationship between fork length and fertility obtained at the time of each run upstream would enable an accurate calculation of the annual reproductive potential, assuming no pre-spawning mortality.

We thank F. Marchand and R. Delanoe for technical assistance, and F. Travade (Electricité de France) for the gift of radio-tracking apparatus.

\section{References}

Alabaster, J. S. (1970). River flow and upstream movement and catch of migratory salmonids. J. Fish Biol. 2, 1-13.

Baglinière, J. L., Champigneulle, A. \& Nihouarn, A. (1979). Le frai du saumon atlantique (Salmo salar L.) et de la truite commune (Salmo trutta L.) sur le bassin du Scorff. Cybium (3 sér.) 7, 75-96.

Baglinière, J. L., Maisse, G., Nihouarn, A., Porcher, J. P. \& Le Gloanec, P. M. (1988). Comparaison de deux méthodes d' estimation de la production naturelle de smolts de saumon atlantique (Salmo salar L.). Bull. Fr. Pêche Piscic. 308, 24-34.

Baril, D. \& Gueneau, P. (1986). Radio-pistage de saumons adultes (Salmo salar) en Loire. Bull. Fr. Pêche Piscic. 302, 86-105.

Beall, E. \& Marty, C. (1983). Reproduction du saumon atlantique Salmo salar L. en milieu semi naturel contrôlé. Bull. Fr. Piscic. 289, 77-93.

Beall, E. \& Marty, C. (1987). Optimisation de la reproduction naturelle du saumon atlantique en chenal de frai: influence de la densité des femelles. In La Restauration des Rivières à Saumon (M. Thibault \& R. Billard, eds), pp. 231-238. France: INRA.

Buck, R. J. G. \& Youngson, A. F. (1982). The downstream migration of precociously mature Atlantic salmon, Salmo salar L., parr in autumn; its relation to the spawning migration of mature adult fish. J. Fish Biol. 20,279-288. 
Chapman, D. W., Weitkamp, D. E., Welsh, T. L., Dell, M. B. \& Schadt, T. H. (1986). Effects of river flow on the distribution of chinook salmon redds. Trans. Am. Fish. Soc. 115, 537-547.

Dunkley, D. A. \& Shearer, W. M. (1982). An assessment of the performance of a resistivity of fish counter. J. Fish Biol. 20, 717-737.

Fontenelle, G. (1975). Recherches sur le saumon atlantique (Salmo salar L. 1776) en Bretagne. I-Caractéristiques des saumons atlantiques adultes des principales rivières de Bretagne et de Basse-Normandie. 2-Premiers éléments d'une dynamique de population de saumon atlantique dans un affluent du Blavet, Morbihan: aspects écoethologiques. Thèse 3ème cycle Biologie Animale, Université Rennes. $161 \mathrm{pp}$.

Hawkins, A. D. \& Smith, G. W. (1986). Radio-tracking observations on Atlantic salmon ascending the Aberdeenshire Dee. Scott. Fish. Res. Rep. No. 36, 24 pp.

Heggberget, T. G. (1988). Timing of spawning in Norwegian Atlantic salmon (Salmo salar). Can. J. Fish. Aquat. Sci. 45, 845-849.

Heggberget, T. G., Haukebo, T. \& Veie-Rosvoll, B. (1986). An aerial method of assessing spawning activity of Atlantic salmon, Salmo salar L., and brown trout, Salmo trutta L., in Norwegian streams. J. Fish Biol. 28, 335-342.

Heggberget, T. G., Hansen, L. P. \& Naeoje, T. F. (1988) Within-river spawning migration of Atlantic salmon (Salmo salar). Can. J. Fish. Aquat. Sci. 45, 1691-1698.

Jensen, A. J., Heggberget, T. G. \& Johnsen, B. O. (1986). Upstream migration of adult Atlantic salmon, Salmo salar L., in the River Vefsna, northern Norway. J. Fish Biol. 29, 459-465.

Jones, J. W. (1959). The Salmon. London: Collins. $192 \mathrm{pp.}$

Jones, J. W. \& King, G. M. (1949). Experimental observations on the spawning of the Atlantic salmon (Salmo salar Linn.). Proc. Zool. 119, 33-48.

Manzer, J. L. \& Miki, I. (1986). Fecundity and egg retention of some sockeye salmon (Oncorhynchus nerka) stocks in British Columbia. Can. J. Fish. Aquat. Sci. 43, $1643-1655$.

Marty, C., Beall, E. \& Parot, G. (1986). Influence de quelques paramètres du milieu d'incubation sur la survie d'alevins de saumon atlantique Salmo salar L., en ruisseau expérimental. Int. Revue Hydrobiol. 71, 349-361.

McCleave, J. D., Power, J. H. \& Rommel, S. A., Jr (1978). Use of radio telemetry for studying up-river migration of adult Atlantic salmon (Salmo salar). J. Fish Biol. 12, 549-558.

Power, J. H. \& McCleave, J. D. (1980). Riverine movements of hatchery reared Atlantic salmon (Salmo salar) upon return as adults. Env. Biol. Fish. 5, 3-13.

Solomon, D. J. \& Storeton-West, T. J. (1983). Radiotracking of migratory salmonids in rivers: development of an effective system. Fish. Res. Tech. Rep., MAFF Direct. Fish. Res., Lowestoft No. $75.11 \mathrm{pp}$.

Swain, A. \& Champion, A. S. (1968). Upstream movements of migratory salmonids in relation to river flows on the River Axe, Devon. ICES CM 1968/M: 9. $7 \mathrm{pp}$. (mimeo).

Thioulouse, G. (1971). Le comportement du saumon de l'Allier. Essai d'Ethologie. Scient. Plein Air, Clermont Ferrand, 1, 49 pp.

Turner, G. E. (1975). Timing of migration of Atlantic salmon (Salmo salar) within the Miramichi River system, New Brunswick. ICES CM 1975/M: 24. 4 pp. (mimeo). 